\title{
Risk factors associated with mental health issues in adolescents: a integrative review
}

\author{
FATORES DE RISCO ASSOCIADOS A PROBLEMAS DE SAÚDE MENTAL EM \\ ADOLESCENTES: REVISÃO INTEGRATIVA
}

\section{FACTORES DE RIESGO ASOCIADOS A PROBLEMAS DE SALUD MENTAL EN ADOLESCENTES: REVISIÓN INTEGRADORA}

\section{Agnes Caroline Souza Pinto', Izaildo Tavares Luna², Adna de Araújo Silva ${ }^{3}$, Patrícia Neyva da Costa Pinheiro', Violante Augusta Batista Braga ${ }^{4}$, Ângela Maria Alves e Souza ${ }^{4}$}

\begin{abstract}
Objective: To identify the risk factors associated with mental health issues in adolescents. Method: An integrative review was conducted in four databases with publications from 2007 to 2013. The terms Adolescent and Mental Health were used to search adequate articles as DeCs/MeSH bases. Results: Publications were found in different journals in different fields of knowledge and the quantitative research was the most frequent. The mental health issues were categorized as individual factors; drug related factors, school factors, family factors, social factors and STDs/Aids related factors. The most addressed category was individual factors, with 23 publications. Conclusion: The integrative review allowed to point important questions to be addressed in preventive actions by the health professional, including the nurse, to create a space that works with risk conditioning factors in adolescents for mental health aggravation.
\end{abstract}

\section{DESCRIPTORS}

Adolescent

Mental health

Risk factors

Review

\section{RESUMO}

Objetivo: Identificar os fatores de risco associados a problemas de saúde mental de adolescentes. Método: Revisão integrativa realizada em quatro bases de dados, com publicações de 2007 a 2013. Os descritores Adolescente e Saúde Mental foram utilizados para a busca de artigos, adequados conforme as bases DeCS/MeSH. Resultados: Foram localizadas publicações em diferentes periódicos, em distintos campos do conhecimento, sendo as pesquisas quantitativas as mais frequentes. Os problemas em saúde mental foram categorizados em fatores individuais; fatores relacionados a drogas; fatores escolares; fatores familiares; fatores sociais; e fatores relacionados às DST/aids. A categoria mais abordada na literatura foram os fatores de risco relacionados ao próprio indivíduo, com 23 publicações. Conclusão: A revisão integrativa permitiu apontar questões importantes a serem abordadas em ações preventivas pelo profissional da saúde, inclusive o enfermeiro, para a criação de espaço que trabalhe com fatores condicionantes do risco de adolescentes aos agravos à saúde mental.

\section{DESCRITORES \\ Adolescente \\ Saúde mental \\ Fatores de risco \\ Revisão}

\section{RESUMEN}

Objetivo: Identificar los factores de riesgo asociados a los problemas de salud mental en adolescentes. Método: Se realizó una revisión integradora de artículos publicados entre los años 2007 y 2013 en cuatro bases de datos. Para la búsqueda de artículos, se utilizaron los descriptores: Salud Mental y Adolescencia, conforme a las bases DeCS/MeSH. Resultados: Se encontraron publicaciones en diferentes revistas, en distintos campos de conocimiento, siendo más frecuentes las investigaciones cuantitativas. Los problemas en salud mental fueron categorizados en factores individuales, relacionados con las drogas, escolares, familiares, sociales y relacionados a las ITS/SIDA. La categoría más abordada en la literatura fue la que indicaba los factores de riesgo relacionados al propio individuo, con 23 publicaciones. Conclusión: La revisión integradora permitió identificar tópicos importantes a ser abordados en acciones preventivas por el profesional de la salud, incluyendo el de enfermería, para la creación de espacios que consideren los factores condicionantes de riesgo para problemas de salud mental en adolescentes.

\section{DESCRIPTORES \\ Adolescente \\ Salud mental \\ Factores de riesgo \\ Revisión}

\footnotetext{
${ }^{1}$ Nurse at Instituto Federal do Ceará. Fortaleza, CE, Brazil. agnespinto@hotmail.com ${ }^{2}$ Doctoral student at the Nursing Graduate Program, Universidade Federal do Ceará. Fortaleza, CE, Brazil. ${ }^{3}$ Master of Nursing at Universidade Federal do Ceará/UFC. Fortaleza, CE, Brazil. ${ }^{4}$ Professor at the Nursing Department at Universidade Federal do Ceará/UFC. Fortaleza, CE, Brazil.
} 


\section{INTRODUCTION}

The World Health Organization defines adolescents as individuals with 10 to 19 years old. In reality, they are individuals that are in their second decade of life and face internal conflicts or situations that can compromise directly their mental health ${ }^{(1)}$.

Within the different definitions of mental health, it is assumed that the concept is wider than the absence of mental disorders. It is the ability to manage its own life and the emotions within a wide range of variations without losing the value of what is real and precious ${ }^{(2)}$.

Mental health issues in adolescents that do not receive treatment are associated to low levels of educational achievement, unemployment, use of drugs, risk behaviors, criminality, poor sexual and reproduction health, self-mutilation and inadequate personal care. These factors intensify the risk of morbidity and premature mortality. It implies high social and economic costs once it frequently evolves to higher social maladjustment and aggressive practices with rules violations ${ }^{(3)}$.

The risk factors for mental health issues are widely known and include sexual and physical abuse during childhood; family, school and community violence: poverty, social exclusion and educational disadvantage. Psychiatry disorders, parent's drug abuse and conjugal violence also increase the risks for adolescents as the exposition to social alterations and psychological distress that accompany armed conflicts, natural disasters and other humanitarian crises. The stigma driven to the adolescent with mental disorders and the human rights violations that are subjected to, amplifies the adverse consequences ${ }^{(3-5)}$.

Therefore, mental health issues in adolescents represent important public health challenges worldwide. Preventive measures can help to avoid the development and the risk factors progression faced by adolescents. The early intervention can reduce the risk factors gravity in its growth and development ${ }^{(4)}$.

Adolescents with known mental health needs have better social adaptation, better development at school and they are more likely to become adapted and productive adults than those adolescents whose needs are not answered. The mental health promotion, the prevention and the treatment of problems that arise during the individual construction process reduce the load upon health care systems ${ }^{(6-7)}$.

The mental health protection starts with the parents and family besides the school and community. To educate about mental health can help adolescents to increase their social abilities, amplify the solving problems capacity and intensify self-confidence which can ease the mental health issues and avoid violent and risk behaviors ${ }^{(4,7)}$.
In this context, the nursing role in mental health is extremely important. The nurse becomes the change agent when he/she breaks with the historical medical model practice that disciplines the subject and communities and do not listen or give value to the subject-citizen in its psychosocial needs ${ }^{(8)}$.

Health professionals that act in diverse contexts highlight the importance of knowledge about the topic to elaborate nursing intervention actions together with the adolescents. That justifies the concern in building a review of scientific studies published in this topic, to identify the produced investigations besides helping to build new future studies. From it, came the leading investigation question: What are the risk factors associated with mental health issues in adolescents?

This study aims to contribute with the planning and implementation of mental health care to attend the adolescent as a whole person with mind, body and spirit connected. The objective was to present an integrative literature review to identify the risk factors associated with mental health issues in adolescents.

\section{METHOD}

An integrative review of the risk factors associated with mental health issues in adolescents was conducted. Integrative review is the Evidence-Based Practice (EBP) instrument which allows the synthesis and analysis around the produced knowledge of an investigated theme. It is a research technique with methodological rigor that enhances the review findings' confidence and depth ${ }^{(9)}$.

To operationalize this review, the following steps were followed: to define the inclusion and exclusion criteria; to define the extracted information from the selected studies (to categorize the studies); to analyze and interpret the data; to assess the included studies in the integrative review and to present the review or knowledge synthesis.

The search was conducted in the following databases: Literatura Latino-Americana e do Caribe em Ciências da Saúde (LILACS); National Library of Medicine (MEDLINE), PubMed and in the repository Scientific Electronic Library Online (SCIELO) that contains national and international publications from 2007 to 2013. The terms Mental Health and Adolescent from the Descritores em Ciências da Saúde/Medical Subject Headings (DeCS/ $\mathrm{MeSH}$ ), from the Biblioteca Virtual em Saúde (BVS) were used to find the studies.

The inclusion criteria were: full article, to be available for free in the electronic databases, with publications between 2007 and 2013, studies in Portuguese, Spanish or English. The exclusion criteria were: repeated articles in more than one database and those that did not fulfilled the study objective. 
In the initial search using the terms Mental Health and Adolescent, 1.045 articles were identified. From those, 328 were from LILACS database, 453 were from MEDLINE, 150 from PubMed and 114 from the SciELO repository. From those, 772 articles did not meet the inclusion criteria, leaving 273 articles for analysis which 53 met the research question and were part of the present review. All were original articles and were analyzed with an instrument built for this matter. It contained the following items: title, journal name, year of publication, source location, the study design and research question.

The results were categorized in factors: individual factors, drugs related, school related, family related, social related and STD/Aids related. A synoptic table was built for its presentation. The information discussed was descriptive based on the information from the articles of the 44 journals that were part of this review.

\section{RESULTS}

It was found publications in different journals from different scientific fields. From the studies that were part of this review, $60.4 \%(n=32)$ were stratified as $A 1$,
A2 e B1 from the nursing Qualis. Regarding their country origin, $32 \%(n=17)$ were from United States; $28.3 \%$ $(n=16)$ from Brazil, 11.3\% $(n=6)$ from England; ,5\% $(n=4)$ from Switzerland; 3.8\% $(n=2)$ from Spain, Colombia and Chile and $1.9 \%(n=1)$ from Peru, Jamaica, Ireland and Mexico. Regarding year of publication, $71.7 \% \quad(n=38)$ were published between 2010 and 2013 and 28.3\% $(n=15)$ between 2007 and 2009. In relation to the study design, it was found that quantitative research was more frequent (Table 1).

Table 1 - Study design from indexed studies at LILACS, $M E$ DLINE, PubMed and SciELO from 2007 to 2013, using the terms Mental Health and Adolescent - Fortaleza, CE, 2013

\begin{tabular}{lcc}
\hline Study Design & N & $\mathbf{\%}$ \\
\hline Quantitative/ $^{\text {non-experimental }}{ }^{(10-36)}$ & 27 & 51.0 \\
Qualitative/other $^{(37-48)}$ & 12 & 22.6 \\
Quantitative/experimental $^{(49-56)}$ & 8 & 15.1 \\
Quantitative/quase-experimental $^{(57-62)}$ & 6 & 11.3 \\
\hline Total & $\mathbf{5 3}$ & $\mathbf{1 0 0}$ \\
\hline
\end{tabular}

Table 2 describes the mental health issues faced by adolescents in accordance with the individual, drugs related, school related, family related, social related and STD/Aids related risk factors.

Table 2 - Risk factors distribution and association with mental health issues in adolescents between 2007 to 2013 - Fortaleza, CE, 2013

\begin{tabular}{|c|c|c|}
\hline Risk factors & Identified issues & $\%$ of articles \\
\hline Individual & $\begin{array}{l}\text { Low self-esteem, lower wish to live, depression and anxiety }{ }^{(14-15,19,22-24,33-34,38,48,62)} \\
\text { Attention-defict hyperactivity disorder, oppositional/conduct disorder somatic complaints }{ }^{(11-13,23,25,59,62)} \text {. } \\
\text { Self-aggression or suicide attempt; suicidal ideation }{ }^{(10,13-14,25,56)} \\
\text { Sadness/loneliness feelings }{ }^{(10,34,58)} \\
\text { Insomnia, fatigue, forgetfulness, irritability, difficulty concentrating and feelings of worthlessness }{ }^{(11-12)} \\
\text { Internalizing and externalizing behaviors }{ }^{(23,25)} \\
\text { Aggression/ high levels of anger/interpersonal problems }{ }^{(27)} \\
\text { Neurotic disorders }{ }^{(28)} \\
\text { Abdominal obesity/ self-image }^{(35)} \\
\text { Need to feel pleasure }^{(37)}\end{array}$ & 43.4 \\
\hline Family related & $\begin{array}{l}\text { Domestic violence with physical punishment experience }{ }^{(23-24,31,56)} \\
\text { Difficulties with family relationships (parents and siblings) } \\
\text { Parents and friends influence to use drugs }{ }^{(14,56)} \\
\text { Low emotional support at home during childhood }{ }^{(15,60)} \\
\text { Alcohol abusive parents }{ }^{(47,54)} \\
\text { Parents divorce } 0,19) \text { to de tristeza; átricos. }^{(19)} \\
\text { Family financial problems } \\
\text { Parents with low well-being levels } \\
\text { Bad experience of family communication } \\
\text { Parents that live with or died of HIV/Aids }\end{array}$ & 26.4 \\
\hline Drugs related & $\begin{array}{l}\text { Use of substances (tobacco, alcohol and other drugs) } \\
\text { Psychosocial dysfunction associated with use of drugs }\end{array}$ & 41.5 \\
\hline School related & $\begin{array}{l}\text { Low performance or school drop-out }(15,17,36,38,48) \\
\text { Bdo abandonoenho escolar.gais); ullying }{ }^{(18,36)} \\
\text { Discrimination and racism experience that led to major emotional suffering }{ }^{(19,49)} \\
\text { To belong to social-economic class D or } \mathrm{E}^{(12)} \\
\text { University application processes as a stressful event (Vestibular) }{ }^{(30)} \\
\text { Social pressure from partners and academic life }\end{array}$ & 22.6 \\
\hline Social & $\begin{array}{l}\text { Suffered aggression and physical violence }{ }^{(13,23,29,36,41,48,58)} \\
\text { Sexual abuse experience evolving life threatening and physical injuries }{ }^{(13,22,41,43,51,53)} \\
\text { Gangs involvement }{ }^{(20,61)} \\
\text { Social contact problems and rules violation }{ }^{(25,59)} \\
\text { Legal problems, involvement with auto accidents and violent acts practice }{ }^{(59,61)} \\
\text { To be not working or studying }{ }^{(12)} \\
\text { High frequency of exposition to community violence, theft, assault and firearms use }{ }^{(13)} \\
\text { To be institutionalized or living in a shelter }{ }^{(13)} \\
\text { Urban poverty }{ }^{(47)}\end{array}$ & 32.0 \\
\hline
\end{tabular}


Continuation...

\begin{tabular}{ll}
\hline Risk factors & Identified issues \\
\hline & HIV vertical transmition ${ }^{(40,42,45-46)}$ \\
& Grave sexual violence ${ }^{(13,29,51)}$ \\
& HIV risk behaviors ${ }^{(20,43,46)}$ \\
& Early sexual activity ${ }^{(42)}$ \\
& Problems to adhere to antiretroviral treatment ${ }^{(42)}$ \\
\hline
\end{tabular}

\section{DISCUSSION}

Despite the mental health issues involve all age groups; the need for studies that investigate the risk factors in the adolescent population has been growing in the past years. The theme becomes relevant and also the importance to develop other studies with this same matter.

It is important to note that $77.4 \%(n=41)$ of the articles included presented quantitative method. These studies motivate discoveries that allow clinical practice validation and logic fundamentals to modify practical aspects ${ }^{(63)}$. However, studies with experimental and quasi-experimental design significantly contribute to the evidence-based practice establishment.

It is important to assess the study design once it identifies the optic from which the problem was analyzed. The problem nature determines the most adequate study design. For being inductive, the qualitative design considers the reality as something subjective that can be approached by multiple perspectives. In general, the quantitative design reflects a determinist philosophy based in positivist paradigms, reducing ideas or variable concepts. The knowledge in the quantitative field is a result of the observation, measurement and interpretation of the objective reality ${ }^{(64)}$.

The two approaches are additional and generate important knowledge for the clinical practice. Both designs require research experience, methodological robustness in the research development besides the knowledge for the scientific development ${ }^{(65)}$.

Another important point found by this review is that $66.0 \%(n=35)$ of the articles in this synthesis were published in well classified journals in the international databases, which demonstrates the quality of analyzed journals.

Regarding the publication year, the frequency and studies percentages, $71.7 \%(n=38)$ of the research about this theme were from the last five years. It is noted that nowadays this issue has been in focus which demonstrate the relevance of this discussion.

In relation to the country of publication, it was predominant the studies conducted by researchers linked to universities and health services from United States and Brazil as follow. The Brazilian production focusing adolescence mental health had a crescent growth starting at the investigated years, which indicates the scientific development in mental health questions in the country ${ }^{(66)}$.

The data described in Table 1 demonstrates that adolescence issues in an individual level as low self-esteem, dissatisfaction with life, suicidal ideation, internalization and externalization behaviors, depression and anxiety associated with other psychosis are markers of mental health issues severity in adolescents.

Brazilian studies about risk factors for mental health issues with adolescence samples from diverse social levels ${ }^{(31,56)}$ related that the issues at an individual level are important for the development of psychopathologies in this population.

In the most recent of those ${ }^{(56)}$, interpersonal issues, dissatisfaction with their body and the need to feel pleasure were identified as risk factors for emotional issues as internalization that are characterized by internal or emotional issues as anxiety and depression, and externalization that can be defined as difficulty to follow social rules or disruptive issues as aggression and rules violation.

The specialized literature indicates that depressed adolescents respond less to positive stimulus and protection factors that can harm their self-esteem and satisfaction with life. The probability of any mental health issue to arise is amplified in this group, especially when those factors arise with the first years of adolescence ${ }^{(67-68)}$.

In the family sphere, the issues linked to the domestic violence with physical punishment experience and psychological violence are risk factors that are mostly associated to mental health issues in adolescents. The studies related that adolescents who pass through difficulties in family relationships like arguments between the parents and siblings, parents divorce, alcohol abusive parents and low emotional support during childhood are more likely to develop mental health issues in comparison to those who experience good communication in the family sphere ${ }^{(31)}$.

The analyzed studies highlighted the domestic violence with physical punishment experience as the factor mostly associated with mental health issues in adolescents. It reveals extreme worry due to the nature of this type of violence, mainly because a big parcel of adolescents suffer from this kind of violence from significant people in their lives ${ }^{(31,56)}$.

The bad communication within the family relationships can interfere in the psychological development processes causing low self-esteem, low self-determination and resilience inability. It leads to behavioral, emotional, social, cognitive and physical development risks in the adolescent $^{(69-70)}$.

It is consensus that the family relationship independent of the adolescent cultural context has a fundamental 
function in its psychic structuring. The family relationships containing affection and good communication are protection factors determinants to the adolescent mental health ${ }^{(31)}$.

A risk factor review associated with adolescent mental health issues ${ }^{(71)}$ identified that severe physical marital violence suffered by the mother provokes harmful effects to the adolescent life. Those factors can lead to alcohol and drug consumption, mental suffering symptoms as anxiety, depression, intrusive thoughts, lack of concentration at school, sleep disorders and hyper vigilance ${ }^{(72-73)}$.

A Brazilian study signals that experiencing violence (as the victim or witness) and suffering mental health issues while growing and developing provokes harmful behaviors to social interaction and generates mental health problems to adolescents ${ }^{(56)}$.

It was found an association between mental health issues and alcohol or drugs consumption in international studies. The articles related that adolescents with at least one mental health issue have a higher prevalence for use of drugs, without specification, as a risk factor. Studies developed in England and in the United States based in clinical criteria to psychiatric problems diagnosis in adolescents showed the psychosocial dysfunction associated with use of drugs. The most present psychiatric disorders were anxiety, depression, conduct problems and hyperactivity or attention deficit ${ }^{(74-76)}$.

Besides the existence of national and international research confirming the association between mental health issues and the use of psychoactive substances, it is not a consensual the direction of this association. The literature shows that mental health issues determine the use of drugs ${ }^{(77)}$ while other studies show the opposite relationship ${ }^{(78)}$. National cohort studies associate the adolescents psychopathologies to the use of substances (tobacco and alcohol)(76,79-80). However, to determine the existence or not of an association between psychiatric problems in adolescents and drugs use, it is necessary randomized clinical trials that observe adolescents that do not present both diagnosis (use of drugs and psychiatric problems).

In relation to the school related risk factors including the low performance or school drop-out, a Brazilian study investigated the variables associates to the school failure/ drop-out between adolescents. It showed that from the emotional stand point, the production of irrelevant answers during the execution of some tasks is related to a low quality school performance which leads the adolescent to manifest motor and vegetative anxiety signals. Those factors interfere in the interpersonal relationships establishment process within the adolescents and their peers and in the hierarchical interpersonal relationships, in the solution of conflicts and in following established rules by social conviviality among other situations ${ }^{(81)}$.

Another identified problem in the literature that shows the association between school related risk factors and the development of mental health issues in adolescents is the bullying. American studies adolescent students showed that those victims of frequent episodes of sexual harassment or threat during their school years presented outcomes associated with relationship problems and hyperactivity ${ }^{(82)}$.

Adolescent victims of bullying are more likely to be shy and to have relationship difficulty their peers. Besides the association with hyperactivity, they can show a combination of anxiety, annoying behaviors with their mates, aggressive traces and sometimes low performance or school drop-out ${ }^{(83)}$. The specialized literature relates that the bullying in adolescents can be a factor to the development of anti-social personality disorders and other violent behaviors ${ }^{(84)}$.

International studies associate the emotional anguish between adolescents that experienced discrimination and racism for being part of low socioeconomic levels or for being racial minorities as predictor factors of mental health issues. This finding appears consistently in the literature and relates the negative impact of racial discrimination in the adolescent psychological health ${ }^{(85-88)}$.

The social pressure from the peers and academic life are also associated with adolescence mental health issues, agreeing with the national study results that investigated the use of strategies for adolescents to face problems (coping) during university selection processes and the possible repercussions the mental health of those individuals ${ }^{(30)}$. The adolescents who faced stressful events as university selection processes (vestibular) that did not used strategies to face those related more psychopathologies.

In the social sphere, an identified issue that deserves attention is the presence of sexual abuse with life threatening and physical aggression, aggression and suffered physical violence. Severe physical punishment was also a risk factor associated with mental health issues in adolescents in the studies that are part of the present review, as the findings from international epidemiological studies ${ }^{(56,89-95)}$.

Community violence, small thefts and assaults with or without firearms are severe and important risk factors to adolescence mental health issues ${ }^{(56,89,91,96-97)}$. The violence effects cause fear and excessive or inadequate aggressiveness that harm the adaptation trajectory to affective and emotional stimulus. These effects goes beyond mental health issues and can turn into physical problems during adulthood ${ }^{(56,91)}$.

In the analyzed studies the sexual violence was also a relevant issue, pointed as the factor that induce the adolescent to more risks. Even when the violence was not from a closer time and it is somehow forgotten for a while, at some point, it will be revived during experiences with their peers, in family and social relationships. It could
Risk factors associated with mental health issues in adolescents: a integrative review Pinto ACS, Luna IT, Silva AA, Pinheiro PNC, Braga VAB, Souza AMA 
incentive the adolescent to act lacking conduct in a social context and to sexual practices without protection that increase the risk of unwanted pregnancy or STD/Aids.

\section{CONCLUSION}

The present research identified diverse psychosocial factors associated to adolescence mental health issues, as individual issues, family related, school related and community related among others as predictors of health deterioration in this population. These factors should be considered in promotion programs proposals, prevention and mental health treatments in adolescents.

In synthesis, the analyzed scientific production provided evidence that in some situations that are typical from adolescence as depression, suicidal ideation and dissatisfaction with life. Besides that, precursor factors that lead to adolescence mental health issues were identified as psychosis, anxiety, conduct or eating disorders and toxic substances abuse. In relation to the risk factors with higher probability to adolescence mental health issues, physical, psychological and sexual violence suffered within the family environment constitutes the most severe factor and can lead to psychopathologies, especially in the initial phase of adolescence.

So, the health professional, especially the nurse, as of solid knowledge, should contribute to the community services effectiveness subsidized by guidelines, legislations and public politics in mental health. In scheduled visits to high risk families, the professional should stimulate the good intra familiar relationship aiming to identify by cultural and social changes that break the physical violence nature. This action contributes to the prevention of all types of violence suffered by adolescents.

It is important to highlight that the adolescence mental health protection begins with the parents and the family, the school and the community. It is necessary that health and education professionals to be sensitized and prepared to adopt preventive and health promoter strategies that take in consideration the adolescents' biopsychosocial and cultural aspects.

Without doubts, the care developed by this approach can assume a multiple power. It can contribute for the family, school and society to increase the social abilities, to improve the solving problems ability and to intensify the adolescence self-confidence. The care can diminish the mental health issues in this age group.

It is necessary the commitment from the nurse, the family, the school and the community to end the traditional knowledge and practices focused on the illness and its effects and to adopt a broad action with a compromised care based in an integral assistance. The individual, family and community psychosocial and spiritual aspects should also be considered as part of an integral care for the adolescence phase to be healthy and without risks.

The prevention practices of adolescent health problems independently of the practice scenario should be broken from the biomedical and technicist vision that do not consider the adolescent integrality as a person being built. For this reason, the actions in mental health should be considered transdisciplinary because the psychic and emotional issues during adolescence can affect the following phases of life.

\section{REFERENCES}

1. United Nations; Department of Economic and Social Affairs, Population Division.World Population Prospects: the 2008 revision [Internet]. New York; 2009[cited 2012 May 20]. Available from: http://www.un.org/esa/population/publications/ wpp2008/wpp2008_highlights.pdf

2. Organização Mundial de Saúde (OMS). Relatório Mundial da Saúde. Saúde mental: nova concepção, nova esperança [Internet]. Brasília: Direção Geral de Saúde; 2002 [citado 2012 maio 20]. Disponível em: http://www.who.int/whr/2001/en/ whr01_djmessage_po.pdf

3. Brasil Ministério da Justiça; Secretaria Nacional de Políticas sobre Drogas. Prevenção ao uso indevido de drogas: capacitação para conselheiros e lideranças comunitárias. 3ํㅡㄹ ed. Brasília: SENAD; 2010.

4. Fundo das Nações Unidas para a Infância (UNICEF). O direito de ser adolescente: oportunidade para reduzir vulnerabilidades e superar desigualdades. Brasília: UNICEF; 2011.
5. Benetti SPC, Ramires VRR, Schneider AC, Rodrigues APG, Tremarin D. Adolescência e saúde mental: revisão de artigos brasileiros publicados em periódicos nacionais. Cad Saúde Pública. 2007;23(6):1273-82.

6. Castro DMF. A saúde mental do adolescente entre duas políticas públicas: o Programa Saúde do Adolescente (PROSAD) e a política de saúde mental [dissertação]. Rio de Janeiro: Universidade do Estado do Rio de Janeiro, Instituto de Medicina Social; 2009.

7. Fisher J, Cabral MM, Izutsu T, Vijayakumar L, Belfer M, Omigbodun $\mathrm{O}$. Adolescent mental health in resource-constrained settings: a review of the evidence of the nature, prevalence and determinants of common mental health problems and their management in primary health care. Int J Soc Psychiatry. 2011;57(1 Suppl):v-vii, 9-116. 
8. Oliveira AGB, Alessi NP. O trabalho de enfermagem em saúde mental: contradições e potencialidades atuais. Rev Latino Am Enferm. 2003;11(3):333-40.

9. Mendes KDS, Silveira RCCP, Galvão CM. Revisão integrativa: método de pesquisa para a incorporação de evidências na saúde e na enfermagem. Texto Contexto Enferm. 2008; 17(4):758-64.

10. Carvalho PD, Barros MVG, Santos CM, Melo EN, Oliveira NKR, Lima RA. Prevalência e fatores associados a indicadores negativos de saúde mental em adolescentes estudantes do ensino médio em Pernambuco, Brasil. Rev Bras Saúde Matern Infant. 2011;11(3):227-38.

11. Menezes AMB, Dumith SC, Martínez-Mesa J, Silva AER, Cascaes AM, Domínguez GG, et al. Problemas de saúde mental e tabagismo em adolescentes do sul do Brasil. Rev Saúde Pública. 2011;45(4):700-5.

12. Jansen K, Mondin TC, Ores LC, Souza LDM, Konradt CE, Pinheiro RT, et al. Transtornos mentais comuns e qualidade de vida em jovens: uma amostra populacional de Pelotas, Rio Grande do Sul, Brasil. Cad Saúde Pública. 2011;27(3):440-8.

13. Benetti SPC, Pizetta A, Schwartz CB, Hass RA, Melo VL. Problemas de saúde mental na adolescência: características familiares, eventos traumáticos e violência. Psico-USF. 2010;15(3):321-32.

14. Silva LHP, Borba LO, Paes MR, Guimarães AN, Mantovani MF, Maftum MA. Perfil dos dependentes químicos atendidos em uma unidade de reabilitação de um hospital psiquiátrico. Esc Anna Nery Rev Enferm. 2010;14(3):585-90.

15. Nguyen HT, Dunne MP, Le AV. Multiple types of child maltreatment and adolescent mental health in Viet Nam. Bull World Health Organ. 2010;88(1):22-30.

16. Nayak MB, Korcha RA, Benegal V. Alcohol use, mental health, and HIV-related risk behaviors among adult men in Karnataka. AIDS Behav. 2010;14 Suppl 1:S61-73.

17. McCaffrey DF, Pacula RL, Han B, Ellickson P. Marijuana use and high school dropout: the influence of unobservables. Health Econ. 2010;19(11):1281-99.

18. Milburn NG, Batterham P, Ayala G, Rice E, Solorio R, Desmond $\mathrm{K}$, et al. Discrimination and mental health problems among homeless minority young people. Public Health Rep. 2010;125(1):61-7.

19. Undheim AM, Sund AM. Prevalence of bullying and aggressive behavior and their relationship to mental health problems among 12- to 15-year-old Norwegian adolescents. Eur Child Adolesc Psychiatry. 2010;19(11):803-11.
20. Voisin DR, Neilands TB. Psychosocial challenges facing black high school students in Chicago: does gender matter? J Adolesc Health. 2010;46(6):600-2.

21. Ruzany MH, Rocha S, Rodrigues RD, Andrade CLT, Meirelles ZV, Moura EAF. Problemas de saúde mental dos adolescentes e jovens ribeirinhos do paraíso ecológico da Reserva de Desenvolvimento Sustentável Mamirauá, Amazonas. Pediatr Mod. 2010;1(1):231-7.

22. Romero MI, Santander J, Hitschfeld MJ, Labbé M, Zamora V. Consumo de tabaco y alcohol entre los estudiantes de medicina de la Pontificia Universidad Católica de Chile. Rev Med Chile. 2009;137(3):361-8.

23. Paula CS, Vedovato MS, Bordin IAS, Barros MGSM, D'Antino MEF, Mercadante MT. Saúde mental e violência entre estudantes da sexta série de um município paulista. Rev Saúde Pública. 2008;42(3):524-8.

24. Caputo VG, Bordin IA. Problemas de saúde mental entre jovens grávidas e não-grávidas. Rev Saúde Pública. 2007;41(4):573-81.

25. Zinn-Souza LC, Nagai R, Teixeira LR, Latorre MR, Roberts $\mathrm{R}$, Cooper SP, et al. Factors associated with depression symptoms in high school students in São Paulo, Brazil. Rev Saúde Pública. 2008;42(1):34-40.

26. Gilreath TD, Cederbaum JA, Astor RA, Benbenishty R, Pineda $D$, Atuel $H$. Substance use among military-connected youth: the California Healthy Kids Survey. Am J Prev Med. 2013;44(2):150-3.

27. Price SD, Salekin RT, Klinger MR, Barker ED. Psychopathy and depression as predictors of psychosocial difficulties in a sample of court evaluated adolescents. Personal Disord. 2013;4(3):261-9.

28. Bella M, Villacé B, Lopez de Neira M, Acosta LD, Lucchese MS, Cometto MC, et al. Hospitalización por trastornos mentales y consumo de sustancias en adolescentes. Rev Salud Pública. 2012;16(2):36-45.

29. Rio Navarro J, Cohen J, Rocillo Arechaga E, Zuniga E; Médecins Sans Frontières Evaluation; Action Team-Honduras. Physical and sexual violence, mental health indicators, and treatment seeking among street-based population groups in Tegucigalpa, Honduras. Rev Panam Salud Publica. 2012;31(5):388-95.

30. Silva LSD, Zanini DS. Coping e saúde mental de adolescentes vestibulandos. Estud Psicol. 2011;16(2):147-54.

31. Avanci JQ, Assis SG, Oliveira RVC, Ferreira RM, Pesce RP. Fatores associados aos problemas de saúde mental em adolescentes. Psicol Teor Pesq. 2007;23(3):287-94. 
32. Guzmán Facundo FR, Pedrão LJ, Rodríguez Aguilar L, López García KS, Esparza Almanza SE. Trastornos por consumo de alcohol (audit) en adolescentes y jovenes marginales de bandas juveniles de mexico. Esc Anna Nery Rev Enferm. 2007;11(4):611-8.

33. Souza LDM, Silva RA, Jansen K, Kuhn RP, Horta BL, Pinheiro RT. Suicidal ideation in adolescents aged 11 to 15 years: prevalence and associated factors. Rev Bras Psiquiatr. 2010;32(1):37-41.

34. Nogueira KT, Lopes CS. Associação entre transtornos mentais comuns e qualidade de vida em adolescentes asmáticos. Rev Bras Epidemiol. 2010;13(3):476-8.

35. Marques FA, Legal EJ, Höfelmann DA. Insatisfação corporal e transtornos mentais comuns em adolescentes. Rev Paul Pediatr. 2012;30(4):553-61.

36. Pierobon M, Barak M, Hazrati S, Jacobsen KH. Alcohol consumption and violence among Argentine adolescents. J Pediatr (Rio J). 2013;89(1):100-7.

37. Assis SG, Avanci JQ, Pesce RP, Ximenes LF. Situação de crianças e adolescentes brasileiros em relação à saúde mental e à violência. Ciênc Saúde Coletiva. 2009; 14(2):349-61.

38. Garcia C, Lindgren S. "Life grows between the rocks": Latino adolescents' and parents' perspectives on mental health stressors. Res Nurs Health. 2009;32(2):148-62.

39. Grana RA, Ramo DE, Fromont SC, Hall SM, Prochaska JJ. Correlates of tobacco dependence and motivation to quit among young people receiving mental health treatment. Drug Alcohol Depend. 2012;125(1-2):127-31.

40. Nachman S, Chernoff M, Williams P, Hodge J, Heston J, Gadow KD. Human immunodeficiency virus disease severity, psychiatric symptoms, and functional outcomes in perinatally infected youth. Arch Pediatr Adolesc Med. 2012;166(6):52835.

41. Jina R, Jewkes R, Hoffman S, Dunkle KL, Nduna M, Shai NJ. Adverse mental health outcomes associated with emotional abuse in young rural South African women: a cross-sectional study. J Interpers Violence. 2012;27(5):862-80.

42. Kapetanovic S, Wiegand RE, Dominguez K. Associations of medically documented psychiatric diagnoses and risky health behaviors in highly active antiretroviral therapy-experienced perinatally HIV-infected youth. AIDS Patient Care STDS. 2011;25(8):493-501.

43. Nduna M, Jewkes RK, Dunkle KL, Shai NP, Colman I. Associations between depressive symptoms, sexual behaviour and relationship characteristics: a prospective cohort study of young women and men in the Eastern Cape, South Africa. J Int AIDS Soc. 2010;13:44.
44. Subramaniam GA, Ives ML, Stitzer ML, Dennis ML. The added risk of opioid problem use among treatment-seeking youth with marijuana and/or alcohol problem use. Addiction. 2010;105(4):686-98.

45. Chernoff $M$, Nachman S, Williams P, Brouwers P, Heston J, Hodge J, et al. Mental health treatment patterns in perinatally HIV-infected youth and controls. Pediatrics. 2009;124(2):627-36.

46. Mellins CA, Elkington KS, Bauermeister JA, Brackis-Cott E, Dolezal C, McKay M, et al. Sexual and drug use behavior in perinatally HIV-infected youth: mental health and family influences. J Am Acad Child Adolesc Psychiatry. 2009;48(8):810-9.

47. Leonard NR, Gwadz MV, Cleland CM, Vekaria PC, Ferns B. Maternal substance use and HIV status: adolescent risk and resilience. J Adolesc. 2008;31(3):389-405.

48. Souza LDM, Ores L, Oliveira GT, Cruzeiro ALS, Silva RA, Pinheiro RT, et al. Ideação suicida na adolescência: prevalência e fatores associados. J Bras Psiquiatr. 2010;59(4):286-292.

49. Martins SS, Storr CL, lalongo NS, Chilcoat HD. Mental health and gambling in urban female adolescents. J Adolesc Health. 2007;40(5):463-65.

50. Hanson RF, Borntrager C, Self-Brown S, Kilpatrick DG, Saunders $\mathrm{BE}$, Resnick HS, et al. Relations among gender, violence exposure, and mental health: the national survey of adolescents. Am J Orthopsychiatry. 2008;78(3):313-21.

51. Crittenden CP, Boris NW, Rice JC, Taylor CA, Olds DL. The role of mental health factors, behavioral factors, and past experiences in the prediction of rapid repeat pregnancy in adolescence. J Adolesc Health. 2009;44(1):25-32.

52. Morgan S, Rickard E, Noone M, Boylan C, Carthy A, Crowley $S$, et al. Parents of young people with self-harm or suicidal behaviour who seek help: a psychosocial profile. Child Adolesc Psychiatry Ment Health. 2013;7(1):13.

53. Danielson CK, McCart MR, Walsh K, Arellano MA, White $D$, Resnick HS. Reducing substance use risk and mental health problems among sexually assaulted adolescents: a pilot randomized controlled trial. J Fam Psychol. 2012;26(4):628-35.

54. Elgán $\mathrm{TH}$, Hansson $\mathrm{H}$, Zetterlind $\mathrm{U}$, Kartengren $\mathrm{N}$, Leifman $\mathrm{H}$. Design of a web-based individual coping and alcohol-intervention program (web-ICAIP) for children of parents with alcohol problems: study protocol for a randomized controlled trial. BMC Public Health. 2012;12:35. 
55. Rigter H, Pelc I, Tossmann P, Phan O, Grichting E, Hendriks V, et al. INCANT: a transnational randomized trial of multidimensional family therapy versus treatment as usual for adolescents with cannabis use disorder. BMC Psychiatry. 2010;10:28.

56. Sá DGF, Bordin IAS, Martin D. Fatores de risco para problemas de saúde mental na infância/adolescência. Psicol Teor Pesq. 2010;26(4):643-52.

57. Stahlberg Ola, Anckarsater H, Nilsson T. Mental health problems in youths committed to juvenile institutions: prevalences and treatment needs. Eur Child Adolesc Psychiatry. 2010;19(12):893-903.

58. Rodríguez-Hernández A, Cruz-Sánchez Ede L, Feu S, Martínez-Santos R. Sedentarismo, obesidad y saludmental en la población española de 4 a 15 años de edad. Rev Esp Salud Pública. 2011;85(4):373-82.

59. Cortés Arboleda MR, Cantón Duarte J, Cantón-Cortés D. Characteristics of sexual abuse of minors and its consequences on victims' mental health. Gac Sanit. 2011;25(2):157-65.

60. Lee SJ, Detels R, Rotheram-Borus MJ, Duan N. The effect of social support on mental and behavioral outcomes among adolescents with parents with HIV/AIDS. Am J Public Health. 2007;97(10):1820-6.

61. Facundo FRG, Pedrão LJ. Fatores de risco pessoais e interpessoais no consumo de drogas ilícitas em adolescentes e jovens marginais de bandos juvenis. Rev Latino Am Enferm. 2008;16(3):368-74.

62. Andrade RC, Assunção Junior FA, Teixeira IA, Fonseca VAS. Prevalência de transtornos psiquiátricos em jovens infratores na cidade do Rio de Janeiro (RJ, Brasil): estudo de gênero e relação com a gravidade do delito. Ciênc Saúde Coletiva. 2011;16(4):2179-88.

63. Ohlsen RI, Peacock G, Smith S. Developing a service to monitor and improve physical health in people with serious mental illness. J Psychiatr Ment Health Nurs. 2005;12(5):614-9.

64. Driessnack NM, Sousa VD, Mendes IAC. Revisão dos desenhos de pesquisa relevantes para enfermagem: part 2: desenhos de pesquisa qualitativa. Rev Latino Am Enferm. 2007; 15(3):684-8.

65. Mynayo MCS, Sanches O. Quantitative and qualitative methods: opposition or complementarity? Cad Saúde Pública. 1993;9(3):239-62.

66. Benetti APC, Ramires VRR, Schneider AC, Rodrigues AP, Tremarin D. Adolescência e saúde mental: revisão de artigos brasileiros publicados em periódicos nacionais. Cad Saúde Pública. 2007;23(6):1273-82.
67. Field T, Sandberg D, Garcia R, Vega-Lahr N, Goldstein $\mathrm{S}$, Guy L. Pregnancy problems, postpartum depression and early mother-infant interactions. Develop Psychol. 1985;21(6):1152-6.

68. Maughan A, Cicchetti D, Toth SL, Rogosch FA. Early-occurring maternal depression and maternal negativity in predicting young children's emotion regulation and socioemotional difficulties. J Abnorm Child Psychol. 2007;35(5):685-703.

69. Assis SG, Avanci JQ. Labirinto de espelhos: Formação da autoestima na infância e na adolescência. Rio de Janeiro: Fiocruz; 2004.

70. Assis SG, Pesce RP, Avanci J. Resiliência: enfatizando a proteção na adolescência. Porto Alegre: Artmed; 2006.

71. Maia J, Williams L. Fatores de risco e fatores de proteção ao desenvolvimento infantil: uma revisão da área. Temas Psicol. 2005;13(2):91-103.

72. Martinez P, Richters JE. The NIMH community violence project: II. Children's distress symptoms associated with violence exposure. Psychiatry. 1993;56(1):22-35.

73. Buka SL, Stichick TL, Birdthistle I, Earls FJ. Youth exposure to violence: prevalence, risks, and consequences. Am J Orthopsychiatry. 2001;71(3):298-310.

74. Audrain-McGovern J, Rodriguez D, Kassel JD. Adolescent smoking and depression: evidence for self-medication and peer smoking mediation. Addiction. 2009;104(10)1743-56.

75. Boys A, Farrell M, Taylor C, Marsden J, Goodman R, Brugha T, et al. Psychiatric morbidity and substance use in young people aged 13-15 years: results from the Child and Adolescent Survey of Mental Health. Br J Psychiatry. 2003;182:509-17.

76. Dierker LC, Avenevoli S, Merikangas KR, Flaherty BP, Stolar $M$. Association between psychiatric disorders and the progression of tobacco use behaviors. J Am Acad Child Adolesc Psychiatry. 2001;40(10):1159-67.

77. Ernst M, Luckenbaugh DA, Moolchan ET, Leff MK, Allen R, Eshel $\mathrm{N}$, et al. Behavioral predictors of substanceuse initiation in adolescents with and without attention-defi cit/hyperactivity disorder. Pediatrics. 2006;117(6):2030-9.

78. Goodman E, Capitman J. Depressive symptoms and cigarette smoking among teens. Pediatrics. 2000;106(4):748-55.

79. Costello EJ, Erkanli A, Federman E, Angold A. Development of psychiatric comorbidity with substance abuse in adolescents: effects of timing and sex. J Clin Child Psychol. 1999;28(3):298-311.
Risk factors associated with mental health issues in adolescents: a integrative review Pinto ACS, Luna IT, Silva AA, Pinheiro PNC, Braga VAB, Souza AMA 
80. Rohde P, Lewinsohn PM, Brown RA, Gau JM, Kahler CW. Psychiatric disorders, familial factors and cigarette smoking: I. Associations with smoking initiation. Nicotine Tob Res. 2003;5(1):85-98.

81. Miguel RR, Rijo D, Lima, LN. Fatores de risco para o insucesso escolar: a relevância das variáveis psicológicas e comportamentais do aluno. Rev Port Pedagog. 2012;46(1): 127-43.

82. Gruber JE, Fineran S. The impact of bullying and sexual harassment on middle and high school girls. Violence Against Women. 2007;13(6):627-43.

83. Olweus D. Bullying at school: what we know and what we can do. Oxford: Blackwell; 1993.

84. Lopes Neto AA. Bullying: comportamento agressivo entre estudantes. J Pediatr (Rio J). 2005;81(5 Supl):S164-72.

85. Sellers RM, Shelton JN. The role of racial identity in perceived racial discrimination. J Pers Soc Psychol. 2003;84(5):1079-92.

86. Wong CA, Eccles JS, Sameroff A. The influence of ethnic discrimination and ethnic identification on African American adolescents' school and socioemotional adjustment. J Pers. 2003;71(6):1197-232.

87. Simons RL, Murry V, McLoyd V, Lin KH, Cutrona C, Conger RD. Discrimination, crime, ethnic identity, and parenting as correlates of depressive symptoms among African American children: a multilevel analysis. Dev Psychopathol. 2002;14(2):371-93.

88. Fisher $C B$, Wallace $S A$, Fenton RE. Discrimination distress during adolescence. J Youth Adolesc. 2000;29(6):679-95.
89. Kaplan SJ, Pelcovitz D, Salzinger S, Weiner M, Mandel FS, Lesser $\mathrm{ML}$, et al. Adolescent physical abuse: risk for adolescent psychiatric disorders. Am J Psychiatry. 1998;155(7)954-9.

90. Shaw BA, Krause N. Exposure to physical violence during childhood, aging, and health. J Aging Health. 2002;14(4):467-94.

91. Springer KW, Sheridan J, Kuo D, Carnes M. Long-term physical and mental health consequences of childhood physical abuse: results from a large population-based sample of men and women. Child Abuse Negl. 2007;31(5):517-30.

92. Benvegnú LA, Fassa AG, Facchini LA, Wegman DH, Dall'Agnol MM. Work and behavioural problems in children and adolescents. Int J Epidemiol. 2005;34(6):1417-24.

93. Bordin I, Paula C. Estudos populacionais sobre saúde mental de crianças e adolescentes brasileiros. In: Mello MF, Mello AA, Kohn R, organizadores. Epidemiologia da saúde mental no Brasil. Porto Alegre: Artmed; 2006. p. 119-42.

94. Fleitlich B, Goodman R. Social factors associated with child mental health problems in Brazil: cross sectional survey. BMJ. 2001;323(7313):599-600.

95. Vitolo YL, Fleitlich-Bilyk B, Goodman R, Bordin IA. Parental beliefs and child-rearing attitudes and mental health problems among schoolchildren. Rev Saúde Pública. 2005;39(5):716-24.

96. World Health Organization (WHO). World report on violence and health. Geneva: WHO; 2002.

97. Cicchetti D, Toth SL. Child maltreatment. Ann Rev Clin Psychol. 2005;1:409-38. 